\title{
Manajemen Berbasis Sekolah: \\ Partisipasi Masyarakat dalam Implementasi Memajukan Dunia Pendidikan
}

\author{
Mukani \\ SMA Negeri 1 Jombang \\ Email:mlorah42@gmail.com
}

\begin{abstract}
This article is a book review created by Ibtisam Abu-Duhou's entitled School Based Management. This is very representative book as one of the main references in understanding the school-based management (SBM) concept, since it was compiled at the very beginning when the SBM concept was introduced in Indonesia. This book consists of five chapters. The discussion begins with a review of the basic concepts, origins and character of SBM decentralization. The first chapter examines the main character of reforms and education management aspects relatively centralistic and decentralized. The second chapter discusses some research in English-speaking countries to provide answers and concrete evidence from the SBM movement. The third chapter describes the radical overall implementation of SBM in Victoria, Australia. The fourth chapter provides an example of the approach and efforts made by policy makers in identifying problems. The fifth chapter elaborates further on the material in the previous chapters to summarize the reform main characters. One consequence of implementing SBM is the realization of community participation, even as spirit and substance. Community participation is a concept of school empowerment in order to improve the quality and school independence. In implementing the SBM concept, community participation has many forms, both in educational, cultural or institutional interaction patterns.
\end{abstract}

Keywords: SBM, Community Participation, Implementation

\section{Pendahuluan}

Pendidikan Islam, secara teoritis, termasuk masalah sosial, sehingga dalam kelembagaannya tidak lepas dari lembaga-lembaga sosial yang ada. Maksud dari lembaga sosial, menurut Hendropuspito, adalah suatu pola tingkah laku, peranan-peranan dan relasi yang terarah dalam mengikat individu yang memiliki otoritas formal dan sanksi hukum, guna terciptanya kebutuhan-kebutuhan sosial dasar. ${ }^{1}$ Lembaga sosial ini, dalam setiap perkembangannya, mengalami transformasi sosial-budaya.

Berbagai fenomena sosial tersebut selanjutnya menjadikan tantangan-tantangan baru bagi lembaga pendidikan Islam, terutama pendidikan formal. Bentuk tantangan yang dihadapi dalam pendidikan Islam adalah masalah politik, kebudayaan, ilmu pengetahuan dan teknologi, ekonomi, masyarakat dan perubahan sosial dan sistem nilai. Berbagai tantangan ini mengandung implikasi bahwa lembaga pendidikan Islam memiliki peran ganda, yaitu sebagai pewaris budaya (agent of conservative) dan pelopor perubahan dalam lingkungan masyarakat (agent of change), termasuk pesantren, sebagai lembaga pendidikan Islam yang lahir dan berkembang secara orisinil dari Indonesia. ${ }^{2}$

${ }^{1}$ Abdul Mujib dan Jusuf Mudzakkir, Ilmu Pendidikan Islam (Jakarta: Kencana, 2006), 113.

${ }^{2}$ Soleh Subagja, Gagasan Liberalisasi Pendidikan Islam (Malang: Media, 2010), 22-28. 
Artikel ini adalah book review karya Ibtisam Abu-Duhou berjudul School Based Management. ${ }^{3}$ Penulis buku ini adalah seorang guru besar di the University of Melbourne. Sejak 1997, Abu-Duhou bekerja sebagai konsultan dalam bidang perencanaan dan kebijakan pada Kementerian Pendidikan Tinggi Palestina.

Buku ini sangat representatif sebagai salah satu referensi utama dalam memahami konsep manajemen berbasis sekolah (MBS), terlebih buku ini disusun pada saat awalawal konsep MBS diperkenalkan di Indonesia. Pemahaman komprehensif tentang konsep MBS diharapkan mampu menjembatani untuk menjadi salah satu alternatif solusi dari berbagai problematika yang dihadapi lembaga-lembaga pendidikan Islam saat ini, terutama dari perspektif manajemen.

\section{Pembahasan}

\section{A. Kajian Buku}

Buku ini diawali dengan penelahan terhadap konsep dasar, asal mula dan karakter dari desentralisasi manajemen sekolah atau MBS, suatu hal yang menjadi kecendrungan pada era 1990-an. Implementasi dari ini telah diperjuangkan oleh berbagai lembaga, terhadap sekolah dengan tujuan meningkatkan efesiensi dan efektivitas pendidikan sekolah itu sendiri. Hal ini telah menjadi isu sangat kontroversial, terutama di kalangan para peneliti tentang efektivitas sekolah dan leadership sekolah yang kuat, sebagaimana juga peran serta masyarakat dan orang tua siswa dalam meningkatkan efektivitas sekolah. Buku ini secara mendetail memberikan pandangan dengan evaluasi terhadap imperatif kependidikannya.

Dalam pembahasannya, disadari bahwa problem yang muncul dalam mengemplementasikan MBS adalah menyeimbangkan perbedaan, fleksibilitas dan pengawasan lokal dengan tanggung jawabnya untuk menjamin bahwa penyelenggaraan pendidikan model seperti ini merata di antara lintas bangsa, sosialekonomi dan perbedaan etnik di masyarakat. Dengan kata lain, pertanyaan kuncinya adalah bagaimana cara dan mekanisme untuk menjamin tingkat pelaksanaan pendidikan yang lebih bagus dan merata, tanpa kontrol sentralistik yang relatif tinggi. Inilah yang disajikan dalam buku ini dengan suatu pendekatan dan pedoman (guidelines) yang sistematis tentang berbagai upaya dari para pembuat keputusan di tingkat pusat mampu mengatasi persoalan-persoalan tersebut.

Diperlukan pengembangan terhadap serangkaian model pemikiran kultural yang "lebih segar" kembali karena pola sentralisme yang telah usang dan hierarki yang birokratis sangat bertolak belakang dengan teori modern tentang otoritas lokal dan pelayanan dari pusat. Kepemimpinan yang didelegasikan dari pusat perlu untuk menggugah para kepala sekolah dan pemerintah agar mereka dapat menerima masukan, kerjasama dan dana yang memadai dari pada terjadi suatu otoritas yang semu dan sumber daya yang terpangkas. Ketika fokus terhadap alokasi sumber daya dalam MBS menentukan keadilan sistem, maka leadership di tingkat pusat dan lokal

${ }^{3}$ Ibtisam Abu-Duhou, School Based Management (Paris: Unesco, 1999). 
benar-benar merupakan faktor krusial dalam menentukan kesuksesan implementasi sistem desentralisasi. Oleh karena itu, pemikiran yang diadopsi dalam buku ini adalah bahwa di tempat yang mempertahankan gerakan tentang sentralisasidesentralisasi manajemen sekolah, seperti yang terjadi di Australia, Selandia Baru, Ingris dan Kanada, maka leadership di level yang lebih tingggi telah berhasil mengubah kultur tentang sistem pendidikan. Lebih jauh lagi, peran kepemimpinan kepala sekolah di tingkat satuan pendidikan tampaknya cukup krusial untuk keberhasilan sistem manajemen ini.

Dampak nyata berbagai upaya terhadap desentralisasi pendidikan melalui MBS di banyak negara maju dan berkembang masih belum menyakinkan. Sebagaimana dilaporkan World Bank, faktor-faktor yang menjadikan MBS menjadi kebijakan menarik biasanya adalah faktor-faktor yang membuat penerapannya menjadi sulit. Jadi, di satu sisi sejumlah negara terus mengupayakan legislasi untuk memberikan pengalihan kewenangan tanggung jawab yang lebih besar kepada sekolah dan masyarakat lokal, di sisi lain sejumlah negara lainnya terus mempertahankan legislasi untuk memberikan pengawasan yang sentralistik terhadap aspek-aspek penyelenggaraan pendidikan, seperti dalam hal standar dan akses terhadap program-program pendidikan. Dalam hal ini, penyelenggaraan pendidikan mencakup segala bentuk kebijakan untuk penataan administrasi, finansial dan organisasi sistem pendidikan yang telah terwujud sebagai hasil dari legislasi di tingkat parlemen atau di level otoritas lokal.

Orientasi dari desentralisasi muncul dari tingkat lokal, seperti yang terjadi di Eropa timur dan beberapa negara di bagian Amerika Serikat. Namun di beberapa negara lainnya, pengalihan (devolution) kewenangan lokal ini tidak muncul dari kalangan guru dan para pendidikan, tetapi justeru dipaksakan dari luar melalui para pemimpin politik yang hendak mencapai produktivitas pendidikan dan ekonnomi yang lebih meningkat, yang meliputi desentralisasi kontrol, penyelenggara pendidikan dan sistem sekolah. Faktor ekonomi ternyata menentukan karakter proses restrukturisasi, karena pemerintah pusat mengkaitkan pembangunan ekonomi dengan tenaga kerja terdidik.

Potensi produktivitas bangsa yang meningkat dianggap berhubungan secara langsung dengan kemajuan umum hasil tes ini. Beare (1991) menegaskan bahwa para politisi telah mendominasi agenda resktrukturisasi pendidikan, karena terdapat rasa tidak percaya kepada para pendidik. Oleh karena itu, para politisi yang ingin mengimplementasikan tuntutan ekonomi telah mendesak untuk mengambil kebijakan di bidang pendidikan. Beare lebih jauh memaparkan bahwa karena pencapaian ekonomi menyangkut produktivitas dan perusahaan cenderung melakukan hal yang sama, maka bentuk dan struktur pendidikan mayoritas cenderung berorientasi kepada kemungkinan dukungan terhadap usaha di sektor ekonomi swasta agar mampu bertahan dalam kondisi post-industrial. Meskipun demikian, keadilan, kualitas, efektivitas lebih besar dan dapat meningkatkan kualitas 
para lulusannya, sebagai akibat dari implementasi MBS ini, masih belum diperlihatkan.

Setelah mendefinisikan MBS dan membedakan beberapa pandangan tentang desentralisasi, bab pertama buku ini mengkaji karakter utama reformasi dan aspek manajemen pendidikan yang relatif sentralistik dan desentralistik. ${ }^{4}$ Pertanyaanpertanyaan yang diusung dalam bab ini mencakup berbagai hal tentang hakikat MBS, hal-hal yan didesentralisasikan, asumsi dasar, karakter dan kecenderungan utama dari reformasi tersebut. Bab ini menguraikan konsep desentralisasi sebagai suatu alat penyelenggara pendidikan untuk melimpahkan kewenangan lebih besar dari kantor pusat (kementerian) pusat ke tingkat lokal (sekolah). Terkait dengan kecenderungan desentralisasi, bab ini mengkaji beberapa argumentasi untuk melakukan restrukturisasi penyelenggaraan sekolah dan gerakan menuju MBS.

Beberapa definisi tentang MBS dalam bab ini menegaskan bahwa konsep tersebut mengacu kepada manajemen sumber daya di tingkat sekolah dan bukan di suatu sistem atau tingkat yang sentralistik. Beberapa sumber daya dalam pengertian lebih luas telah didefinisikan mencakup pengetahuan, teknologi, kekuasaan, material, manusia, waktu dan keuangan. Melalui MBS, beberapa sekolah diberi pengawasan lebih besar atas arah yang akan dicapai organisasi sekolah tersebut. Tujuan dan strategi untuk mencapai semua itu terutama ditentukan di tingkat sekolah. Pengawasan atas anggaran dianggap merupakan inti dari MBS, yang meliputi pengawasan atas penetapan peran, penggajian dan pengembangan staf.

Sejumlah studi kasus di beberapa penelitian di negara yang berbahasa Inggris berada di bab kedua untuk memberikan jawaban dan bukti kongkrit dari gerakan tersebut. ${ }^{5}$ Secara khusus, studi kasus ini diambil dari Australia, Kanada, Hongkong, Selandia Baru, Inggris dan Amerika Serikat. Contoh dari beberapa negara lainnya, termasuk negara yang tidak berbahasa Inggris dan negara berkembang, juga disinggung dan dipertimbangkan. Studi kasus dan contoh tersebut dimaksudkan untuk menunjukkan pelaku dan kekuatan utama di balik reformasi, ciri-cirinya dan hasil, jika diketahui, dari reformasi tersebut.

Kajian dalam bab ini memperlihatkan bahwa MBS telah didukung banyak lembaga, baik pemerintahan maupun non-pemerintahan, yang menginginkan pengawasan sekolah lokal lebih besar dengan tujuan meningkatkan efisiensi dan efektivitas pendidikan sekolah. Bab ini memberikan uraian rinci mengenai berbagai reformasi dari berbagai pandangan. Yang perlu menjadi catatan penting di sini adalah pengalaman negara Kanada, yang berkonsentrasi kepada penyerahan sumber daya keuangan ke sekolah-sekolah melalui anggaran berbasis sekolah dan pendanaan formula. Inisiatif Manajemen Sekolah (IMS) di Hongkong memberikan fleksibilitas yang lebih besar kepada sekolah dalam menggunakan sumber daya,

${ }^{4}$ Ibid, 23-35.

Ibid, 36-61. 
sementara pada saat yang sama memungkinkan partisipasi lebih besar dari para guru, orang tua dan para alumni dalam pengambilan keputusan.

Gerakan MBS di Inggris terdiri dari beberapa reformasi, seperti kurikulum nasional, sistem ujian berbasis prestasi dikaitkan dengan kurikulum nasional, pilihan siswa tentang sekolah dan manajemen sekolah lokal yang melakukan desentralisasi sebagian besar anggaran bagi lingkungan sekolah serta memberikan kewenangan kepada sekolah-sekolah untuk memilih dan merekrut staf. Sistem inisiatif manajemen sekolah dan manajemen sekolah lokal memberikan fleksibilitas dan otonomi lebih besar bagi masyarakat lokal dalam pengambilan keputusan, yang mengakibatkan tanggung jawab lebih besar kepada orang tua, pengusaha dan masyarakat luas. Sistem serupa juga diperkenalkan di Selandia Baru. Di Amerika Serikat, masing-masing negara bagian mengadopsi strategi-strategi yang berbeda dalam meningkatkan sistem yang ada. Misalnya, MBS di beberapa negara bagian dikaitkan dengan sistem akuntabilitas yang terkait pada prestasi siswa, tetapi tidak di negara bagian lain. Di beberapa negara bukan berbahasa Inggris, pengalamanpengalaman tersebut berbeda-beda dari pengawasan lokal dan penyerahan manajemen sampai kepada penyerahan keuangan dan otonomi.

Pada bab ketiga buku ini dideskripsikan pelaksanaan menyeluruh secara radikal dari MBS di Victoria, Australia dan merinci perkembangan historisnya, para pelaku utama dalam merancang kebijakan, rancangan implementasi, proses evaluasi dan proses penerapannya. ${ }^{6}$ Reformasi ini telah dipilih karena signifikansinya terhadap para perencana dan administrator pendidikan. Tujuan bab ini adalah membantu para perencana dan pengambil kebijakan untuk memahami peran aktual yang dimainkan oleh berbagai pelaku dalam reformasi dan proses penerapannya. Salah satu ciri utama dari MBS adalah kebijakan mengenai mekanisme pendanaan dan mengalokasikan sumber daya yang diadopsi oleh beberapa negara. Perlu diakui bahwa prosedur alokasi sumber daya yang berdampak terhadap setiap aspek operasi sekolah pasti akan menentukan persamaan sistem tersebut.

Digambarkan, sebagai Sekolah Masa Depan (SMD), pengembangan MBS di Victoria sudah berkembang selama 20 tahun. Model ini menghasilkan penyusunan kembali tanggung jawab, kewenangan dan akuntabilitas. Kurang lebih dari dua tahun sejak dimulainya inisiatif tersebut, lebih dari 1.700 sekolah negeri menjadi manajemen mandiri dan memiliki pengawasan atas anggaran mereka sendiri, menutupi lebih dari 90 persen pengeluaran, dengan kepala sekolah memiliki kewenangan dalam memiliki staf.

Reformasi tersebut bertujuan meningkatkan kualitas pendidikan bagi siswa dengan melimpahkan tanggung jawab kepada sekolah untuk mengambil keputusan, menentukan prioritas dan mengawasi sumber daya serta bekerja sesuai dengan empat elemen. Elemen pertama, kerangka kurikulum yang membuat standar bagi kejelasan prestasi siswa di hampir semua sekolah. Kerangka ini membantu sekolah

${ }^{6}$ Ibid, 62-92. 
dalam merumuskan dan mengimplementasikan prosedur untuk mencapai masingmasing visinya, membuat program sendiri, bersamaan dengan mempertimbangkan identitas, aspirasi dan kepentingan guru. Elemen kedua, kerangka manusia yang berkaitan dengan struktur karir tenaga kerja pendidikan dan pengembangan staf di sekolah. Elemen ketiga, kerangka sumber daya. Kerangka ini mengalokasikan lebih dari 90 persen anggaran langsung ke sekolah, memberikan fleksibilitas kepada sekolah dalam mengalokasikan semua sumber daya sesuai dengan kebutuhan belajar siswa dan membiayai sekolah dengan cara jelas dan adil melalui Anggaran Global Sekolah (AGS). Elemen keempat, kerangka akuntabilitas. Kerangka ini menjadi mekanisme utama bagi prestasi sekolah yang dipantau, baik melalui piagam sekolah dan serangkaian laporan dan pemeriksaan lainnya.

Telaah ini memberikan beberapa observasi penting, yang menjadi perhatian para perencana pemdidikan dan pengambil kebijakan di kementerian pendidikan di bagian negara lain. Pertama adalah pendorong efisiensi dan efektivitas pendidikan yang digambarkan program SMD, memperlihatkan sistem yang direstrukturisasi dan penentuan konsep prestasi yang menuntut keahlian dalam berbagai keterampilan dari dewan sekolah dan kepala sekolah. Ambiguitas proses desentralisasi terletak pada pelimpahan tanggung jawab atas alokasi sumber daya kepada sekolah, bahkan hak tetap memiliki kewenangan dalam menilai, memeriksa dan mengarahkan kembali aktivitas di lingkungan sekolah manapun. Namun, pemahaman yang jelas tentang pembatasan proses desentralisasi membantu dalam memecahkan masalah tersebut.

Kedua, berkaitan dengan AGS. AGS pada dasarnya merupakan model pembiayaan berbasis formula yang terdiri dari elemen dasar bagi semua sekolah, bersama-sama dengan elemen keadilan berdasarkan kepada karakteristik siswa yang mendaftar. AGS memberikan pembiayaan bagi semua pengeluaran berbasis sekolah, temasuk gaji staf dan tunjangannya, pembiayaan operasional dan pemeliharaan sekolah. AGS terdiri dari dua komponen, yaitu komponen inti, yang berdasarkan kepada masing-masing jumlah siswa sekolah dan komponen indeks, yang berdasarkan kepada karakteristik pembelajaran khusus siswa.

Ketiga adalah model pembiayaan AGS bertujuan untuk memenuhi kebutuhan pendidikan siswa itu sendiri di masing-masing sekolah. Kategorinya meliputi siswa cacat dan lemah jasmani, di daerah terpencil atau pedesaan, siswa dengan resiko pendidikan dan berlatar belakang bukan berbahasa Inggris. Prinsip anggaran keunggulan pendidikan, transparansi, subsidi, akuntabilitas dan implementasi strategis perencanaan pembiayaan digunakan dalam alokasi sumber daya ini. Namun, ketegangan akuntabilitas dan sentralisasi menjadi faktor penghambat kebebasan tersebut. Meskipun mampu mengarahkan pendanaan sesuai dengan agenda lokal, sekolah juga dihadapkan kepada ukuran akuntabilitas yang tinggi.

Keempat berkaitan dengan satu hal penting dalam AGS. Hal ini merupakan pendanaan yang meningkat bagi pendidikan masa kanak-kanak, yang 
mempertimbangkan bahwa belajar anak selama masa persiapan sampai kelas dua adalah penting untuk mengembangkan kemampuan membaca dan berhitung mereka. Ini merupakan keberhasilan mereka di kelas berikutnya.

Kelima berkaitan dengan penggunaan teknologi dan komputerisasi sistem informasi untuk menjalankan dan memantau fungsi sistem administratif di tingkat pusat dan lokal. Hal ini disertai dengan pengunaan teknologi untuk menyampaikan kurikulum ke daerah perkotaan, pedesaan dan daerah terpencil.

Keenam terkait erat dengan peranan pemimpin dalam mengubah sistem budaya. Di Victoria, gerakan bertahap untuk semua sekolah menjadi SMD dijalankan oleh posisi pemerintah yang kuat dan menteri pendidikan yang percaya terhadap nilai keterlibatan masyarakat lokal di sekolah. Kementerian tersebut menyediakan semua pendanaan yang diperlukan untuk menutupi biaya proses restrukturisasi dan melimpahkan kewenangan serta tanggung jawab penuh ke tingkat sekolah. Elemen informasi untuk membantu semua sekolah dalam transisi menuju MBS. Reformasi ini memperkuat dorongan bagi kepala sekolah agar diakui sebagai pemimpin sejati sekolah mereka serta membangun dan mengarahkan tim pengajaran (teaching team) dengan menjelaskan tanggung jawab penting yang ditentukan di tingkat sekolah. Peran kepemimpinan di sebagian besar tingkat lebih tinggi, dalam hal ini Menteri Pendidikan, berhasil mengubah budaya sistem dan peranan kepala sekolah di tingkat sekolah, yang hal ini penting bagi keberhasilan sekolah dengan manajemen mandiri.

Terakhir, gerakan bertahan untuk semua sekolah menjadi SMD ini menimbulkan perdebatan tentang isu individual, namun bukan tentang nilai sistem itu sendiri. Nilai pemerintah berkaitan dengan efisiensi, otonomi dan kebebasan, namun biasanya dikaitkan sesuai dengan model yang dipengaruhi pasar, lagi pula sejak implementasi kebijakan pemerintah bagi MBS cenderung tidak prioritas ekonomi, maka isu seperti keadilan sosial dan persamaan hak dalam kesempatan pendidikan berada dalam bahaya yang terabaikan. Pengaruh penyerah keuangan dapat dipersoalkan seperti keadilan dalam sekolah manajemen mandiri akan dibahas dalam bab berikut.

Dalam buku ini, bab keempat memberikan contoh pendekatan pada petunjuk yang sistematis tentang berbagai upaya yang dilakukan para pembuat kebijakan di kantor pusat dalam mengidentifikasi masalah tersebut. ${ }^{7} \mathrm{Hal}$ ini disebabkan karena hinggga sekarang terdapat kekurangan penelitian tentang efektifitas sekolah dalam memperoleh basis penilaian prosedur yang memberdayakan para kepala sekolah dan guru yang dipraktekkan dalam sekolah manajemen mandiri. Meskipun begitu, Caldwell menunjukkan bahwa beberapa ahli pendidikan, selama lebih dari 20 tahun, terus bergelut dengan upaya mengembangkan lebih jauh sekolah swa-kelola. Dengan manajemen tersebut, para guru harus dikaryakan oleh dewan sekolah dan

${ }^{7}$ Ibid, 93-111. 
garis kewenangan bergerak dari kepala sekolah ke ketua dewan sekolah, yang pada gilirannya bertanggung jawab kepada masyarakat.

Sebaliknya, Smyth menggambarkan proses devolusi sekolah sebagai suatu proses yang disengaja dari alasan, distoris, penyembunyian dan pengabaian yang disengaja karena negara mencoba mundur dengan cara yang agak kurang terhormat dari tanggung jawab historisnya untuk memberikan pendidikan publik yang berkualitas. Dengan adanya pilihan atas desentralisasi, pemerintahan nasional belum menunjukkan bahwa efektifitas sekolah atau hasil (outcomes) nasional belum menujukkan bahwa efektifitas sekolah atau outcomes siswa telah meningkat. Akan tetapi, secara teoritis, ketentuan alokasi anggaran global tahunan yang adil bagi sekolah atas dasar suatu kebutuhan, dapat mempertanggungjawabkan persoalan keadilan. Pengakuan terhadap kebutuhan yang menentukan alokasi sumber daya bagi sekolah di Edmonton Public Schools District (dan di Australia) menggambarkan dua usaha dalam membahas masalah keadilan. Derivasi dan evolusi formula pendanaan berbasis kebutuhan yang berjalan terus ini menuntut keahlian suatu sikap responsif di pusat sistem. Sekolah harus mampu membuktikan dan secara meyakinkan menunjukkan kebutuhannya, mempengaruhi derivasi suatu formula pendanaan yang responsif. Kebutuhan khusus yang muncul dengan tidak didugaduga dapat diganti untuk ditinjau kembali.

Bidang yang paling problematik dalam menentukan alokasi anggaran adalah bagi staf. Apakah sekolah harus membayar staf sesuai dengan pengeluaran gaji yang sebenarnya atas kerja nyata di sekolah (school by school) atau apakah harus ada gaji kotor yang dapat diterapkan dalam sistem tersebut? Caldwell dan Spink melaporkan bahwa Inggris dan Wales memilih yang pertama dan Edmonton memilih yang terakhir. Mereka berdua menunjukkan bahwa persoalan yang menimbulkan perdebatan ini sering kali membuka kedok "ketidakadilan utama dalam biaya staf tradisional dan biaya setiap siswa" sekarang ini. Persatuan guru sangat sensitif terhadap ancaman ini bagi gaji anggotanya. Damaine mengingatkan ancaman yang dirasakan tersebut diajukan kelompok "kanan baru" di Inggris dengan mengatakan bahwa kelompok "kanan baru" telah mengangap pengalihan skala gaji nasional guru, pembuatan ulang kontrak guru itu sendiri dan pemisahan kapasitas guru dalam kegiatan serikat buruh sebagai hal penting dalam penentuan pelayanan pendidikan yang meningkat.

Dalam kaitan dengan faktor-faktor lain yang akan memajukan keadilan dalam sistem MBS, penulis buku sependapat dengan Caldwell dan Spink yang telah mengidentifikasi perlunya memperbaiki dan meningkatkan formula pengalokasian sumber daya secara terus menerus bagi sekolah atas dasar suatu kebutuhan. Lagi pula, tampaknya harus hati-hati dalam memberikan "jaringan pengaman" selama masa transisi dalam mengantisipasi perubahan yang cepat dalam prioritas sistem atau keadaan lokal. Faktor penting untuk memajukan keadilan dalam suatu sistem yang didesentralisasi adalah budaya di pusat. Rasa tanggung jawab, sebagai suatu 
aspek budaya pelayanan, harus ditunjukkan jika sekolah diberi kepercayaan untuk memenuhi harapan masyarakat.

Pada negara-negara Barat, megatrend pendidikan ke arah desentralisasi dan MBS telah berjalan selama 20 tahun lalu. Dorongan ke arah sistem tersebut digerakkan oleh para politisi dan ahli ekonomi untuk menciptakan tenaga kerja terdidik yang lebih baik agar meningkatkan produktivitas nasional dan menguatkan struktur ekonomi. Sumber daya yang ada dialokasikan bagi sekolah manajemen mandiri atas dasar kebutuhan dan jumlah siswa serta para kepala sekolah dan dewan sekolah dianggap bertanggung jawab atas distribusinya. Kualitas manajemen keuangan di tingkat sekolah menentukan efektifitas banyak aspek lingkungan belajar, termasuk pengetahuan dalam kurikulum, materi, teknologi, orang dan waktu. Peranan leadership kepala sekolah adalah faktor yang banyak permintaannya, yang mempengaruhi banyak aspek kinerja sekolah. Leadership tranformasional, suatu model yang belum bisa dilaksanakan, baik di tingkat sekolah maupun sistem, tampaknya menghasilkan pemberdayaan, kepercayaan, sinergi, akuntabilits dan rasa pelayanan yang diperlukan bagi manajemen yang berhasil di tingkat sekolah.

Bab lima dalam buku ini memaparkan lebih jauh materi pada bab-bab terdahulu untuk menyimpulkan karakter utama reformasi, untuk memetakan bagaimana hal tersebut dapat diimplementasikan oleh para perencana dan pengelola pendidikan, untuk menyimpulkan butir-butir kunci yang terlihat ketika satu kementerian pendidikan memutuskan, untuk memilih manajemen berbasis sekolah, dan untuk menjawab kecenderungan yang mungkin terjadi di masa depan. ${ }^{8}$ Bagian ini juga menjelaskan bahwa kesuksesan implementasi MBS diadvokasi oleh banyak pihak, baik pemerintah maupun organisasi non-pemerintah, sehingga efisiensi dan efektivitas pendidikan di sekolah mampu terwujud.

\section{B. Partisipasi Masyarakat}

Konsep School-Based Management (SBM), sebagaimana judul dalam buku di atas, di Indonesia lebih dikenal dengan istilah manajemen berbasis sekolah atau MBS. Konsep ini baru digulirkan di Indonesia pasca Gerakan Reformasi Mei 1998 yang mengakhiri sistem sentralistik dari pemerintah pusat. Pendidikan, sebagai salah satu bidang yang didelegasikan dari pemerintah pusat kepada daerah, merupakan hal yang mengiringi otonomi daerah yang diberlakukan. Pasca implementasi UU Nomor 22 Tahun 1999 tentang Otonomi Daerah, desentralisasi dan otonomi pendidikan diharapkan mampu mengurangi cengkeraman pusat terhadap sekolah. ${ }^{9}$

Konsep MBS, sebenarnya memiliki berbagai konsekuensi saat sudah diimplementasikan dalam dunia pendidikan. MBS, dalam bidang kurikulum, mendorong setiap sekolah untuk menyusun kurikulum tingkat satuan pendidikan (KTSP). Setiap sekolah, berapapun jarak lokasinya dengan sekolah lain,

${ }^{9}$ Supriono dan Achmad Sapari, Manajemen Berbasis Sekolah (Surabaya: SIC, 2001), 2. 
diperbolehkan memiliki visi, misi dan program yang berbeda dengan sekolah yang lain. Namun, visi, misi dan program yang dirancang harus tetap dalam kerangka besar untuk pencapaian tujuan pendidikan nasional.

Pada bidang pendanaan, implementasi MBS mendorong setiap sekolah untuk "semakin cerdas" dalam memperoleh sumber biaya. Kondisi ini dilatarbelakangi adanya pemahaman bahwa dunia pendidikan juga menjadi tanggung jawab masyarakat, bukan hanya pemerintah. Namun, konsistensi Indonesia untuk mengimplementasikan MBS patut dipertanyakan. Pada sekolah-sekolah negeri, independensi pembiayaan dari pemerintah masih belum diwujudkan, terlebih dalam membiayai rutin pendidik dan tenaga kependidikan. Pada sekolah swasta, terlebih sekolah dengan networking mumpuni dalam hal pembiayaan, kewajiban ini bukan menjadi sesuatu hal yang berat.

Secara global, meskipun sudah lebih dari 20 tahun otonomi pendidikan diberlakukan, konsep MBS di Indonesia belum mampu berjalan sesuai dengan yang dikehendaki. Terdapat adanya empat pilar utama dalam mensukseskan implementasi MBS di Indonesia yang belum berjalan secara maksimal, yaitu partisipasi masyarakat, transparansi, kemandirian dan kualitas proses belajar mengajar. Dengan melihat realita tersebut, tidak mengherankan jika MBS di Indonesia masih berjalan di tempat.

Partisipasi masyarakat dalam implementasi konsep MBS mutlak diperlukan, bahkan sebagai ruh dan substansi. Selain dalam hal pengelolaan, partisipasi aktif masyarakat dalam mengelola sekolah juga berperan untuk memberikan kesempatan kepada siswa untuk mengembangkan komitmen kepada aksi, sehingga mereka mampu untuk meneliti nilai-nilai insani secara kritis dan menguji nilai-nilai mereka sendiri. ${ }^{10}$ Integrasi personal dari nilai-nilai etis dan religius yang mendorong orang berbuat sesuatu, jauh lebih penting daripada kemampuan menghapalkan fakta dan pendapat-pendapat dari orang lain.

Partisipasi masyarakat dalam implementasi MBS juga merupakan suatu keniscayaan yang tidak bisa dihindari. Masyarakat merupakan lingkungan yang pertama dan utama bagi sekolah, semua siswa yang berada di sekolah berasal dari masyarakat sekitar, siswa akan tinggal di sekitar sekolah sepanjang 24 jam. Masyarakat merupakan salah satu sumber pemasukan uang pemerintah, oleh karena itu masyarakat merupakan aset penting dalam pembangunan, termasuk dalam dunia pendidikan.

Partisipasi masyarakat, dalam kerangka MBS, merupakan konsep pemberdayaan sekolah dalam rangka peningkatan mutu dan kemandirian sekolah. Melalui implementasi MBS, diharapkan para pengelola sekolah dan masyarakat setempat dapat melaksanakan pendidikan sesuai dengan kebutuhanm perkembangan jaman, karakteristik lingkungan dan tuntutan global. Dalam dunia pendidikan, pemberdayaan masyarakat merupakan cara yang paling praktis dan

${ }^{10} \mathrm{~J}$. Drost, Dari KBK Sampai MBS (Jakarta: Kompas, 2005), 123. 
produktif untuk memperoleh hasil terbaik dari kepala sekolah selaku manajer, para guru dan para pegawai. Proses yang ditempuh adalah dengan membagi tanggung jawab secara proporsional kepada para guru. Satu prinsip terpenting dalam pemberdayaan ini adalah melibatkan guru dalam proses pengambilan keputusan dan tanggung jawab. Melalui proses pemberdayaan itu diharapkan para guru memiliki kepercayaan diri (self reliance). ${ }^{11}$

Banyak ahli pendidikan menulis tentang jenis-jenis partisipasi masyarakat dalam upaya pembangunan, termasuk di bidang pendidikan, yang dimulai dari tingkat terendah sampai ke tingkat tertinggi. Susunan yang dimaksud adalah, (1) hanya dalam menggunakan jasa pelayanan yang tersedia, misalnya memasukkan anak ke sekolah, (2) peran serta dengan memberikan kontribusi dana, bahan dan tenaga, (3) peran serta dalam bentuk keikutertaan, yang berarti menerima secara pasif segala hal yang telah diputuskan oleh pihak lain, seperti keputusan komite sekolah yang memutuskan jumlah dana yang harus dibayar setiap siswa, (4) peran serta melalui adanya konsultasi mengenai hal-hal tertentu, seperti kepala sekolah yang berkonsultasi kepada komite sekolah terkait program-program sekolah, (5) keterlibatan dalam memberikan layanan pendidikan tertentu, biasanya sebagai mitra pihak lain, seperti kerjasama komite sekolah yang mewakili sekolah dalam mendatangkan puskesmas untuk memberikan penyuluhan kesehatan kepada siswa, (6) keterlibatan sebagai pelaksana kegiatan yang telah didelegasikan, seperti permintaan pihak sekolah yang meminta komite sekolah memberikan penyuluhan tentang pentingnya bersekolah bagi anak di suatu desa tertentu, (7) peran serta yang sebenarnya dalam pengambilan keputusan pada berbagai jenjang, seperti komite sekolah yang ikut serta membahas dan mengambil keputusan tentang rencana kegiatan sekolah, baik kegiatan maupun pendanaannya. ${ }^{12}$

Pemberdayaan dan partisipasi masyarakat dilakukan dalam beberapa tahap. Pertama masyarakat mulai mengembangkan sebuah kesadaran awal bahwa mereka dapat melakukan tindakan untuk meningkatkan kehidupannya dan memperoleh seperangkat keterampilan agar mampu bekerja lebih baik. Kedua, mereka akan mengalami pengurangan perasaan ketidakmampuan dan mengalami peningkatan kepercayaan diri. Akibatnya, pada tahap ketiga, seiring dengan tumbuhnya keterampilan dan kepercayaan diri, masyarakat bekerja sama untuk berlatih lebih banyak dalam mengambil keputusan dan memilih sumber-sumber daya yang akan berdampak pada kesejahteraan mereka.

Sedikitnya terdapat delapan langkah pemberdayaan, dalam kaitan dengan implementasi MBS, yaitu (1) menyusun kelompok guru sebagai penerima awal atas rencana program pemberdayaan, (2) mengidentifikasi dan membangun kelompok peserta didik di sekolah, (3) memilih dan melatih guru dan tokoh masyarakat yang terlibat secara langsung dalam implementasi manajemen berbasis sekolah, (4)

${ }^{11}$ E. Mulyasa, Manajemen Berbasis Sekolah (Bandung: Remaja Rosdakarya, 2009), 31-32.

${ }^{12}$ Supriono dan Achmad Sapari, Manajemen Berbasis Sekolah, 13-14. 
membentuk komite sekolah, yang terdiri dari unsur sekolah, unsur masyarakat di bawah pengawasan pemerintah daerah, (5) menyelenggarakan pertemuanpertemuan para anggota komite sekolah, (6) mendukung aktivitas kelompok yang sedang berjalan, (7) mengembangkan hubungan yang harmonis antara sekolah dengan masyarakat, (8) menyelenggarakan lokakarya untuk evaluasi. ${ }^{13}$

Dalam implementasi konsep MBS, partisipasi masyarakat memiliki bentuk yang sangat banyak. Di antara bentuk yang dimaksu adalah (1) memberikan dukungan dana atau sumbangan yang berupa fisik saja, (2) merencanakan kegiatan dan kemungkinan pendanaan kegiatan-kegiatan tersebut, (3) ikut menambah guru yang tidak ada, atau kurang, bahkan bersedia menjadi "guru" pengganti, (4) memberikan masukan dan mendiskusikan pelaksanaan pembelajran, kinerja para guru, prestasi belajar anak, kendala yang dihadapi dan sebagainya, (5) dalam pelaksanaan peran serta masyarakat yang sudah ideal, masyarakat juga dapat terlibat dalam memilih dan memasukkan guru-guru yang diperlukan sekolah serta memberhentikan guru yang prestasinya tidak memuaskan.

Menurut Ngalim Purwanto, terdapat tiga pola interaksi hubungan masyarakat dengan sekolah yang dapat dikembangkan. Pertama adalah hubungan edukatif. Pola ini dilaksanakan dalam hal mendidik siswa, antara guru di sekolah dan orang tua di dalam keluarga. Hubungan ini dimaksudkan agar tidak terjadi perbedaan prinsip atau bahkan pertentangan yang dapat mengakibatkan keraguraguan pendirian dan sikap pada diri siswa. Kedua adalah hubungan kultural. Pola ini dilaksanakan antara pihak sekolah dengan masyarakat dalam membina dan mengembangkan kebudayaan masyarakat tempat sekolah itu berada. Pada konteks ini, tidak mengherankan jika sekolah lalu dijadikan barometer bagi kemajuan, kemunduran, cara berpikir, kesenian, kebudayaan dan berbagai hal yang terjadi di dalam masyarakat. Ketiga adalah hubungan institusional. Pola ini dilaksanakan melalui kerjasama yang dilakukan pihak sekolah dengan berbagai lembaga atau instansi resmi lainnya, baik swasta ataupun pemerintah. ${ }^{14}$ Kerja sama ini misalnya dilakukan sekolah dengan puskesmas, dinas pertanian, pasar, pemerintahan setempat dan sebagainya, yang semua itu dilakukan dalam rangka perbaikan dan kemajuan pendidikan.

Berbagai cara dapat dilakukan oleh pihak sekolah untuk meningkatkan partisipasi masyarakat. Pihak sekolah bisa mengundang para orang tua siswa, komite sekolah dan tokoh masyarakat dalam sebuah diskusi tentang upaya-upaya dalam meningkatkan mutu pendidikan di sekolah. Sekolah juga harus berupaya menjelaskan kepada masyarakat bahwa tanggung jawab pendidikan bukan hanya pada pemerintah, melainkan juga masyarakat. Kepala sekolah dan dewan guru juga harus memberikan kepercayaan kepada masyarakat untuk turut serta dalam mengelola keuangan sekolah, terutama yang bersumber dari masyarakat sendiri.

${ }^{13}$ E. Mulyasa, Manajemen Berbasis Sekolah, 33.

${ }^{14}$ Supriono dan Achmad Sapari, Manajemen Berbasis Sekolah, 14-15. 
Kepala sekolah sudah saatnya mengimplementasikan open management, sehingga trust akan muncul di kalangan masyarakat kepada pihak sekolah, terlebih trust dari para orang tua siswa. ${ }^{15}$

Dalam mewujudkan pemberdayaan masyarakat untuk menghasilkan partisipasi masyarakat dalam konteks implementasi MBS, terdapat beberapa hal yang harus memperoleh perhatian, yaitu (1) community organization atau pemberdayaan berhubungan erat dengan upaya peningkatan kemampuan masyarakat untuk memegang kontrol atas diri dan lingkungannya, sehingga perlu dilakukan pembangunan yang bersifat lokal, mengutamakan dan merupakan aksi sosial dan menggunakan pendekatan organisasi kemasyarakatan setempat, (2) self management and collaboration atau adanya kesamaan dan kesepadanan kedudukan dalam hubungan kerja, sehingga prinsip yang dilaksanakan adalah manajemen yang swakelola oleh para guru dan kepala sekolah, kepemilikan oleh masyarakat sebagai akibat dari tumbuhnya rasa memiliki dalam diri masyarakat terhadap kemajuan sekolah, pemantauan langsung oleh pemerintah daerah, tumbuhnya rasa kebersamaan dan kolektivitas dengan unsur-unsur lainnya, (3) participatory approaches atau menggunakan pendekatan partisipatif, sehingga ada kebersamaan saat merumuskan tujuan sekolah, menyikapi proses MBS sebagai proses dialog dan melakukan pembangunan sendiri, (4) education for justice atau pendidikan untuk keadilan, sehingga prinsip-prinsip yang harus dijalankan adalah mengembangkan kesadaran kritis, menggunakan metode diskusi dalam kelompok kecil, menggunakan stimulus berupa masalah-masalah, menggunakan sarana sebagai alat untuk refleksi tentang realitas, memusatkan perhatian pada pengembangan sistem sosial daripada individu-individu, mengutamakan penyelesaian konflik secara win-win solution, menjalin hubungan antarmanusia yang bersifat non-hierarkis dan menggunakan fasilitator yang komit terhadap pembebasan. Keempat hal inilah yang disebut dengan ciri proses pemberdayaan sebagai tahapan dasar dalam MBS. Sedangkan Kindervatter menyebutkan terdapat delapan karakteristik pemberdayaan masyarakat, yaitu (1) penyusunan kelompok kecil, (2) pengalihan tanggung jawab, (3) pimpinan oleh partisipan, (4) guru sebagai fasilitator, (5) proses bersifat demokratis dan hubungan kerja yang luwes, (6) merupakan integrasi antara refleksi dengan aksi, (7) metode yang mendorong kepercayaan diri, (8) meningkatkan derajat kemandirian sosial, ekonomi dan politik. ${ }^{16}$

\section{Analisis}

Buku karya Ibtisam Abu-Duhou ini, berdasarkan kajian sekilas, hampir memiliki model studi yang sama dengan tulisan Clive A. J. Dimmock. ${ }^{17}$ Dalam buku berjudul School-based Management and School Effectiveness, Dimmock menjelaskan secara rinci tentang hubungan antara MBS, keefektivan sekolah dan berbagai trik dalam

${ }^{15} \mathrm{Ibid}, 16$.

${ }^{16}$ E. Mulyasa, Manajemen Berbasis Sekolah, 33-35.

${ }^{17}$ Clive A. J. Dimmock, School-based Management and School Effectiveness (tk: Routledge, 1993). 
pengembangan sekolah. Penjelasan ini merupakan hasil penelitian yang komplit tentang tema di atas di Australia, Selandia Baru, Kanada dan Amerika Serikat. Dimmock juga mendeskripsikan secara gamblang tentang perubahan pendidikan, paradigma yang seharusnya dimiliki guru dalam menghadapi perubahan, visi dan kultur sekolah dalam perubahan serta berbagai analisis tentang ketercapaian efektivitas secara prinsipil.

Kajian tidak jauh berbeda juga pernah dilakukan Susan Albers Mohrman dan Priscilla Wohlstetter. ${ }^{18}$ Kedua penulis, melalui buku berjudul School-based Management: Organizing for High Performance, sebenarnya memberikan kontribusi yang signifikan melalui literatur dalam hal perkembangan sekolah, terutama data-data tentang MBS. Melalui karya kedua berjudul School-based Management: Promise and Process, kedua penulis juga mendeskripsikan tentang urgensi MBS dalam mengembangkan sekolah menuju institusi pendidikan bermutu. ${ }^{19}$ Studi serupa juga pernah dilakukan oleh Jerry John Herman dan Janice L. Herman. ${ }^{20}$

Sedangkan konsep MBS yang dikaji secara detail dalam buku Ibtisam AbuDuhou ini, sebenarnya bukan sesuatu yang harus diistimewakan. Hal ini mengingat, di samping segi positif, juga memiliki segi negatif. MBS sudah dilaksanakan di Australia, sebagai negara yang pertama kali memiliki konsep tersebut sejak tahun 1970-an, di Indonesia konsep ini dilaksanakan pada jenjang SLTP baru pada tahun 1997-an, disusul kemudian jenjang SLTA pada tahum 1998-an dan terakhir pada jenjang SD pada tahun 2000-an. Meskipun demikian, implementasi MBS dalam ketiga jenjang tersebut belum mampu memberikan perubahan yang signifikan untuk melahirkan perbaikan dalam perkembangan pendidikan di tanah air.

Hal itu lebih disebabkan kultur masyarakat yang belum mampu dan siap untuk menyambut kehadiran MBS, di samping pemahaman stakeholders terhadap konsep MBS yang juga belum mapan. Artinya, partisipasi masyarakat yang merupakan pilar utama dalam mengeplementasikan MBS ternyata belum terwujud. Masyarakat lebih berasumsi bahwa tanggung jawab dalam pelaksanaan programprogram tersebut dengan tolak ukur out put yang dihasilakan setiap tahunnya. Pihak sekolah sendiri, terlebih kepala sekolah, belum memiliki keberanian yang kuat untuk melaksanakan fungsinya secara benar dalam kerangka MBS. Kepala sekolah masih sangat tergantung kepada "petunjuk atasan" dari pada merealisasikan ide-idenya dalam memajukan sekolah yang dipimpin, sebagai wujud kemandirian sekolah dalam mengambil policy yang terkait erat dengan dengan sekolah yang bersangkutan. Di sisi lain, akuntabilitas realisasi program-program sekolah lebih cenderung disampaikan ke atas dengan prinsip asal bapak senang (ABS), dari pada

\footnotetext{
${ }^{18}$ Susan Albers Mohrman dan Priscilla Wohlstetter, School-based Management: Organizing for High Performance (Michigan : Jossey-Bass Publishers, 1994).

${ }^{19}$ Susan Albers Mohrman dan Priscilla Wohlstetter, School-based Management: Promise and Process (Michigan: Consortium for Policy Research in Education, 1994).

${ }^{20}$ Jerry John Herman dan Janice L. Herman, School-Based Management: Current Thinking and Practice (Michigan: Charles C Thomas Pub Limited, 1993).
} 
mewujudkan transparansi yang luas untuk menarik respon positif dan stakeholders yang seharusnya dilandasi transparansi ternyata masih jauh dari harapan. Dari sini, tidak mengherankan jika partisipasi masyarakat terhadap kemajuan sekolah juga masih sangat minim.

Di sisi lain, peran guru dalam mengelola proses belajar mengajar juga masih belum menunjukkan kemandirian. Guru lebih berpedoman kepada "bentuk jadi" dalam kurikulum mata pelajaran yang diajarkan, yang disusun oleh pemerintah pusat, tanpa adanya upaya kreatif untuk mengembangkan lebih lanjut agar memiliki relevansi dengan realita dan perkembangan jaman. Pendekatan kontekstual dalam mendidik siswa juga belum nampak. Akhirnya kemandirian guru dalam mengelola proses belajar mengajar di kelas hanya sebuah harapan yang utopis, setidaknya sampai detik ini.

Pada perspektif lain, masalah alokasi anggaran kepada bidang pendidikan yang masih sangat minim juga menjadi problem yang tidak boleh begitu saja dikesampingkan. Meskipun pasal 49 ayat (1) dalam UU Nomor 20 Tahun 2003 tentang Sistem Pendidikan Nasional (Sisdiknas) mengamanatkan agar 20\% dari belanja APBN dan APBD dialokasikan untuk kemajuan pendidikan, hal itu masih menjadi mimpi semata. Alokasi anggaran untuk bidang pendidikan di Indonesia hanya sekitar 4,5\% dari APBN yang ada. Klaim berbagai pihak yang menyatakan bahwa alokasi anggaran APBN atau APBD untuk pendidikan sudah di atas 20\%, hitungan itu masih termasuk gaji pendidik. Padahal amanat UU Sisdiknas angka $20 \%$ di luar gaji pendidik dan pendidikan kedinasan.

Jumlah ini masih sangat jauh jika dibandingkan dengan negara-negara ASEAN lainnya, seperti Malaysia, Singapura, Thailand, Brunei Darussalam dan sebagainya. Jika hal ini dibiarkan terus menerus, dikhawatirkan "penyakit-penyakit" dalam pendidikan, seperti korupsi, menjadi tidak bisa dihilangkan. Di sisi lain, semangat untuk mengabdi di dunia pendidikan semakin menurun, mengingat tidak adanya jaminan ketercukupan dari segi ekonomi dan tidak bisa dipungkiri bahwa semua manusia memerlukan hal itu.

Buku ini, dengan melihat berbagai realita yang bervariasi di atas, setidaknya memberikan gambaran tentang konsep MBS dan upaya-upaya dalam mengimplementasikannya di lapangan secara baik dan benar. Meskipun yang dijadikan case study lebih didominasi negara-negara berbahasa Inggris, tidak termasuk Indonesia, namun hal itu justeru diharapkan mampu menjadi semacam motivator untuk mewujudkan kondisi yang dibahas dalam buku ini. Di sisi lain, implementasi konsep MBS dalam buku ini hendaknya tetap memperhatikan berbagai hal, terutama kultur masyarakat yang berbeda di antara Indonesia dengan kultur negaranegara yang dibahas dalam buku tersebut. Akhirnya, ada suatu hal yang menjadi pertanyaan besar, yaitu terkait niat untuk "sekedar belajar" memahami konsep MBS dengan benar, dan terlebih lagi mengimplemintasikannya secara konsisten.

Meskipun demikian, tulisan dalam buku ini sebenarnya memberikan suatu alternatif untuk menata kembali manajemen pendidikan Islam. Khazanah intelektual 
yang terjabar dengan begitu luasnya dari peradaban Islam harus tetap dipelihara dengan baik agar menjadi pemicu diraihnya kejayaan Islam pada masa mendatang. Itu semua akan mampu mewujud saat manajemen pendidikan Islam dikelola dengan baik. Jika hal ini tidak dilakukan secara cermat, maka implementasi MBS pada lembaga pendidikan Islam hanya akan menjadi utopia belaka.

\section{Catatan Akhir}

Buku karya Ibtisam Abu-Duhou ini terdiri dari lima bab. Pembahasan diawali dengan penelahan terhadap konsep dasar, asal mula dan karakter dari desentralisasi MBS. Bab pertama mengkaji karakter utama reformasi dan aspek manajemen pendidikan yang relatif sentralistik dan desentralistik. Bab kedua membahas tentang beberapa penelitian di negara yang berbahasa Inggris untuk memberikan jawaban dan bukti konkrit dari gerakan MBS. Bab ketiga mendeskripsikan pelaksanaan menyeluruh secara radikal dari MBS di Victoria, Australia. Bab keempat memberikan contoh pendekatan kepada petunjuk yang sistematis tentang berbagai upaya yang dilakukan para pembuat kebijakan di kantor pusat dalam mengidentifikasi masalah tersebut. Bab kelima memaparkan lebih jauh materi pada bab-bab terdahulu untuk menyimpulkan karakter utama reformasi.

Implementasi MBS, salah satu konsekuensinya, adalah perwujudan partisipasi masyarakat. Partisipasi masyarakat dalam implementasi konsep MBS mutlak diperlukan, bahkan sebagai ruh dan substansi, suatu keniscayaan yang tidak bisa dihindari. Partisipasi masyarakat merupakan konsep pemberdayaan sekolah dalam rangka peningkatan mutu dan kemandirian sekolah. Dalam implementasi konsep MBS, partisipasi masyarakat memiliki bentuk yang sangat banyak. Pola interaksi hubungan masyarakat dengan sekolah yang dapat dikembangkan meliputi hubungan edukatif, hubungan kultural dan hubungan institusional. Berbagai cara dapat dilakukan oleh pihak sekolah untuk meningkatkan partisipasi masyarakat. Pihak sekolah bisa mengundang para orang tua siswa, komite sekolah dan tokoh masyarakat dalam sebuah diskusi tentang upaya-upaya dalam meningkatkan mutu pendidikan di sekolah. Dalam mewujudkan pemberdayaan masyarakat untuk menghasilkan partisipasi masyarakat, ada beberapa hal yang harus diperhatikan, yaitu community organization, self management and collaboration, participatory approaches dan education for justice.*

\section{Daftar Rujukan}

Dimmock, Clive A. J. School-based Management and School Effectiveness. tk: Routledge, 1993. Drost, J. Dari KBK Sampai MBS. Jakarta: Kompas, 2005.

Duhou, Ibtisam Abu. School Based Management. Paris: Unesco, 1999.

Herman, Jerry John dan Janice L. Herman, School-Based Management: Current Thinking and Practice. Michigan: Charles C Thomas Pub Limited, 1993

Mohrman, Susan Albers dan Priscilla Wohlstetter. School-based Management: Organizing for High Performance. Michigan: Jossey-Bass Publishers, 1994.

. School-based Management: Promise and Process. Michigan : Consortium for Policy Research in Education, 1994. 
Mujib, Abdul dan Jusuf Mudzakkir. Ilmu Pendidikan Islam. Jakarta: Kencana, 2006.

Mulyasa, E. Manajemen Berbasis Sekolah. Bandung: Remaja Rosdakarya, 2009.

Subagja, Soleh. Gagasan Liberalisasi Pendidikan Islam. Malang: Media, 2010.

Supriono dan Achmad Sapari. Manajemen Berbasis Sekolah. Surabaya: SIC, 2001. 